\title{
Implementing the urban food-water-energy nexus through urban laboratories: a systematic literature review
}

\author{
Darin Wahl $^{1}$ (D) Barry Ness ${ }^{1} \cdot$ Christine Wamsler $^{1}$
}

Received: 22 April 2020 / Accepted: 3 December 2020 / Published online: 3 January 2021

(c) The Author(s) 2021

\begin{abstract}
The sustainability of complex resource systems, such as the food, water, and energy (FWE) nexus, is increasingly threatened by climate change impacts, expanding populations, urbanization, and economic instability. However, while research on the topic has burgeoned, studies focused on solution development and implementation, especially at the urban level, have lagged behind. Against this background, we review the urban FWE nexus literature. We focus on the operationalization of solutions for implementation, and seek to identify opportunities for participatory approaches. Our results suggest that operationalization would benefit from: (1) more fully integrating urban social complexity; (2) extending our understanding of the nexus to include social responses to the impacts of interventions; and (3) ensuring that projects build knowledge that is not only actionable, but also credible, salient, and legitimate. We then discuss the potential of local, transdisciplinary approaches, in the form of urban laboratories, to shift the focus of FWE nexus research towards operationalization. We conclude with five recommendations: (1) knowledge development should extend to implementation; (2) stakeholders should be engaged, and be able to align solutions with the agency to implement; (3) research should move beyond material flows, and focus on the behaviors, habits, and social patterns that underpin urban complexity; (4) FWE nexus thinking should become part of participatory/laboratory approaches; and (5) policymakers should integrate nexus research into municipal strategies and plans.
\end{abstract}

Keywords Urban $\cdot$ Participatory methods $\cdot$ Transdisciplinary $\cdot$ Living labs $\cdot$ Knowledge production $\cdot$ Experimentation $\cdot$ Food-water-energy nexus

\section{Introduction}

There is an increasingly urgent need for urban sustainability solutions to address complex resource systems, such as the food, water, and energy (FWE) nexus. In our increasingly interconnected world, sectoral silos are no longer acceptable ways to approach sustainability challenges, because solutions based only on one sector or discipline will unavoidably

Handled by Daniel J. Lang, Transdisciplinary Sustainability Research, Leuphana University of Lüneburg, Faculty Sustainability, Germany.

Supplementary information The online version of this article (https://doi.org/10.1007/s11625-020-00893-9) contains supplementary material, which is available to authorized users.

Darin Wahl

darin.wahl@lucsus.lu.se

1 Lund University Centre for Sustainability Studies (LUCSUS), Box 170, 22100 Lund, Sweden affect others, whether by design or accident. Such interconnections are particularly evident, and critical in FWE sectors, since each is connected to, and often dependent on, the others. In addition, the sustainability and security of the supply and delivery of FWE resources are increasingly uncertain, due to mounting pressures from climate change, urbanization, population growth, and economic instability (Future Earth 2018).

The concept of the FWE nexus emerged in response to the 2007-2008 energy and food crisis (Allouche et al. 2015), and has gained in popularity since 2011, when an international nexus conference was held in Bonn (Hoff 2011), and the World Economic Forum's 2011 Water Security Report (Waughray 2011) was published. The concept views FWE resources as an integrated and interactive system, and aims to maximize synergies, and minimize trade-offs between resource sectors (Hoff 2011; Bazilian et al. 2011).

To date, research has predominantly been focused on regional and national levels and, in this context, on conceptual issues (e.g. determining what the system consists 
of), and descriptive and analytical aspects (e.g. developing a better understanding of its scope and functioning) (Albrecht et al. 2018). More recently, interest has expanded in two directions: globally, in the context of meeting the 2030 Sustainable Development Goals (e.g. Liu et al. 2018; Simpson and Jewitt 2019b), and locally, with respect to its application in urban development and governance (e.g. Artioli et al. 2017; Newell et al. 2019). However, few studies have examined its operationalization for strategic implementation in society (Albrecht et al. 2018; Simpson and Jewitt 2019b). In their review, Leck et al. (2015, p. 452) observed that we do not yet know "how to implement nexus research and deliver real world solutions at multiple scales and in different contexts". Similarly, Albrecht et al. (2018, p. 20) stated that operationalizing the nexus will require addressing four key features, namely "innovation, social and political context, collaboration, and implementation in policy and practice".

In spite of and, perhaps, because of current challenges, recent reviews suggest that there is an urgent need for pathways to action, and that socially-engaged multi- and inter-disciplinary approaches are key to transforming FWE science (Scanlon et al. 2017; Simpson and Jewitt 2019a). FWE system change is a reflexive, ongoing process that requires interdisciplinary and transdisciplinary coordination to achieve desirable impacts (Scanlon et al. 2017; Allouche et al. 2018; Pahl-Wostl 2019). Implementing sustainability solutions can, therefore, be a lengthy process that, ultimately, requires the participation of a plurality of non-academic actors (Halbe et al. 2015).

Calls are growing to incorporate these considerations, and foster solutions-oriented implementation at the urban level (Romero-Lankao et al. 2017; Liu et al. 2017; Allouche et al. 2018; Simpson and Jewitt 2019a). Cities are drivers of global environmental change (Grimm et al. 2008), and are increasingly seen as key to understanding and managing the FWE nexus. They are also critical arenas for transitioning to sustainability, as they represent a concentration of policy, resource consumption, economic activity, population growth, innovation, and entrepreneurship (Fuenfschilling et al. 2019). Urban contexts are highly complex arenas in which social, ecological, and technical systems are inextricably entangled (McPhearson et al. 2016). The complexity of social systems is especially central in the context of understanding and intervening in the urban FWE nexus. Current and historic socio-cultural, economic, and political constructs influence access to, and the distribution, delivery, and use of FWE resources (Romero-Lankao et al. 2017; Alberti et al. 2018). Therefore, although it is clear that there are strong connections within the FWE nexus at all levels, the urban nexus may need to integrate layers of complexity that do not play a central role at higher levels of analysis.
Against this background, this article presents a review of the urban FWE nexus literature. The aim is to identify its operationalization, i.e. the process of moving from science or knowledge to practice, and opportunities to apply participatory, solution-oriented approaches, with particular emphasis on urban experimentation. Building on recent reviews of the broader FWE nexus (Endo et al. 2017; Albrecht et al. 2018; Shannak et al. 2018; Liu et al. 2018; Simpson and Jewitt 2019b) and, specifically, the urban FWE nexus (Zhang et al. 2019a; Newell et al. 2019), we analyze the literature, and seek to identify the components found in solutions-oriented sustainability science research (Funtowicz and Ravetz 1993; Gibbons 1994). We discuss the conceptual shifts that could re-orient the urban FWE nexus towards solutionsbased, and participatory approaches, such as urban transdisciplinary experimentation. Finally, we conclude with some recommendations with respect to how to engage participatory change processes in the urban FWE nexus.

\section{Methodology}

\section{Literature review}

The Scopus database was searched, in November 2019, using the following string: "food" and "water" and "energy" and "nexus" and ("city" or "cities" or "urban*" or "metropo*" or "suburb*" or "periurban"). The results were filtered for peer-reviewed articles in English. This resulted in a total of 128 papers. Two criteria were then applied: (1) Does the study have a stated focus on the food, water, and energy nexus, and not another nexus (e.g. energy, water, and air), or a binary (e.g. food-water) construct? Studies on, for example, the climate, land, energy, and water nexus were, thus, excluded to maintain a comparative baseline; and (2) does the article state that the primary relevance or impact is at the urban level? Finally, review papers identified by the search were checked for any additional articles that may not have been captured. These were added to the set, while the review papers were removed to avoid duplicates. Following the application of these criteria, the initial dataset was reduced to 55 papers.

\section{Analysis}

The analysis focused on the operationalization of the FWE nexus, and the potential application of participatory, solution-oriented approaches. Thus, the selected papers were examined regarding: (1) their orientation; (2) their conceptual contribution (if any); and (3) participatory methods (if any). Furthermore, we also considered: (4) any proposed future steps, and whether it appeared that non-academic actors had participated. 
In this analysis, operationalization can be studied by identifying any gaps in the strategies and approaches used to move from a descriptive-analytical focus, to the implementation of solutions. We understand implementation as direct action in the social arena. It may take the form of a policy, technical, technological, or other intervention with respect to social constructs, arrangements, or institutions.

Following Wiek and Lang (2016), we suggest that there are two intermediate stages in this transition: proposed solutions and tested solutions. Furthermore, we recognize that, as analyses have predominantly focused on regional and national levels, the reconceptualization of the nexus is a critical step in its operationalization in the urban context. Specifically, the FWE concept must be adapted to integrate social-ecological-technical urban complexities.

\section{Orientation}

The selected papers were divided into four categories: (1) descriptive-analytical, (2) proposed solution, (3) tested solution, or (4) real-world implementation. These orientations reflect different approaches, and address different aspects of the problem.

Typically, descriptive-analytical studies are model- or tool-based, and aim to develop a definition of the FWE nexus system. They address complex interactions as trade-offs or synergies, within and between resource systems in domains that range from production through consumption to waste. In contrast, solution-oriented studies address issues that have been identified: proposed solution studies assess the potential impacts of a change/innovation within the nexus; tested solution studies often take the form of a pilot implementation in a sheltered, niche context; and real-world implementation studies examine the implementation of a solution in society.

\section{Re-conceptualization}

Articles in the dataset were examined regarding their contribution to the reconceptualization of the urban nexus. Operationalization at the urban level requires the incorporation of social complexity, which determines outcomes in cities, into the nexus concept (Foran 2015; Romero-Lankao et al. 2017). Therefore, we were interested in understanding how the nexus concept has been adapted to urban contexts, and for what purpose. Selected studies were examined with respect to the inclusion of non-academic actors, the integration of social complexity, and future steps.

\section{Participatory methods: actors, and implementation processes}

Participation was evaluated by identifying the actor configuration of the study, and any engagement with non-academic actors. Non-academic actors play a key role in mobilizing change processes in multi-level, complex systems (Law 1992; Frantzeskaki et al. 2012; Westley et al. 2013; Pahl-Wostl 2019), and the effective integration of nexus research into governance and policy processes (Newell et al. 2019). Cash et al. (2003) suggest, in the domain of sustainable development, that knowledge must be scientifically grounded (credible), relevant and timely (salient), unbiased, and respect the plurality of stakeholder perspectives and beliefs (legitimate). Non-academic actors can help to indicate knowledge inputs and outputs, the salience and credibility of outputs, and the target of the research. Our review adopted a broad interpretation of participation, as the aim was to capture the involvement of non-academic actors at any stage in the research, including interviews.

Participation was also analyzed in relation to planned implementation processes. Future steps were categorized in terms of, for example, whether more research was recommended, or a pilot study. The analysis also extended to whether the inclusion of other disciplines was recommended.

\section{Results}

Our analysis confirmed the lack of approaches that seek to operationalize sustainability solutions in the urban FWE nexus. Only two (4\%) studies presented a real world implementation of a nexus solution.

Technical solutions were, by far, the most prevalent. Of the $40 \%$ of studies that described potential solutions, they comprised $73 \%$. They were almost equally divided between those that sought to improve resource use efficiency, and those that sought to increase the production of FWE resources (through, for example, urban agriculture, or rooftop solar panels).

Only $7 \%$ of studies could be categorized as participatory. We examine these results in more detail in the following sections, based on data included in Supplementary Material 1.

\section{Orientation}

Our review revealed that the current literature is largely descriptive-analytical, and focused either on quantifying or conceptualizing the urban nexus. Although many studies considered the potential impact of changes in the nexus, few addressed the testing and implementation of sustainability solutions.

\section{Descriptive-analytical}

Descriptive-analytical studies comprised $60 \%$ of the dataset (33 papers). Of these, 70\% (23) used or developed models or tools to quantify the urban nexus (see Fig. 1). 


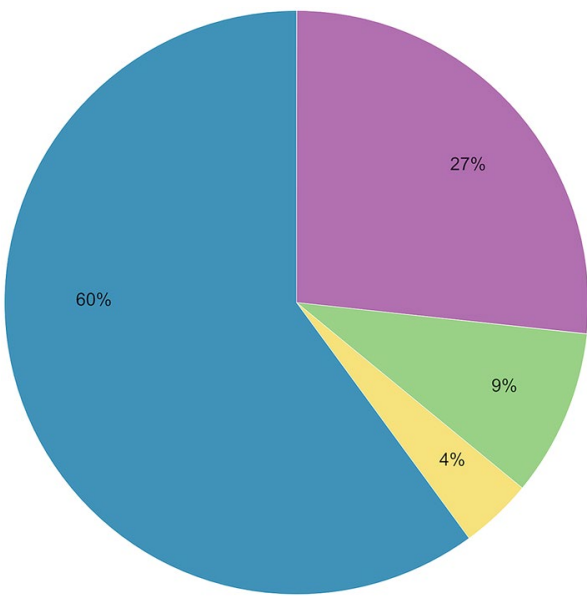

Fig. 1 Distribution of the dataset as a function of orientation. Blue represents descriptive-analytical papers; purple represents proposed solution papers; green represents tested solution papers; and yellow represents real world implementation papers

Models and tools Studies that quantified the urban FWE nexus used various models and tools (Table 1) to understand resource flows. Unsurprisingly, urban metabolism was well-represented, as were input-output and footprint studies (Albrecht et al. 2018; Newell et al. 2019). This group of studies spans multiple levels. For example, Hussien et al. (2017) studied FWE flows at the household level; Chini et al. (2017) and Feng et al. (2019) concentrated on the city level; Zhang, Zhang, Hao et al. (2019a, b) focused on the regional level; and Ramaswami et al. (2017) tested a transboundary urban FWE nexus framework.

Conceptual Of the descriptive-analytical studies, 27\% (9) were conceptual, and proposed a diversity of ways in which to integrate urban social complexity into the nexus.

A clear theme was the need to integrate power, politics, and inequalities. Unequal power dynamics (Covarrubias et al. 2019) are shown to have impacts on justice and resilience (Schlör et al. 2018), access to resources (Martínez-Guido et al. 2019), and health (Giatti et al. 2019). Consequently, Dalla Fontana and Boas (2019) suggested integrating urban political ecology into models. This idea is, in part, exemplified in a model developed by Daher et al. (2019).

Other studies focused on cross-scale or multi-level dynamics. Covarrubias (2019) advocated the need for further analysis to determine pathways that couple material and social flows, while Chirisa and Bandauko (2015) argued that African cities should be considered as a network, to connect the urban nexus with national and regional sustainability strategies and agendas. Schulterbrandt Gragg et al. (2018) used causal loop diagrams to identify cross-scale, multi-level interactions and drivers from local to global levels.

\section{Proposed solutions}

Proposed solutions comprised 27\% (15) studies, and could be divided into two types: urban agriculture (UA) methods, or quantitative models. Both types explore the potential impacts of innovative techniques or technologies. Exceptions examined the potential of decentralized governance (Lahmouri et al. 2019), household investment strategies (Topi et al. 2016), or urban planning (Gondhalekar and Ramsauer 2017). Nearly all studies recommended more research before implementation, often citing the need for a better understanding of how the suggested change would interact with society.

Many solutions are production or efficiency-based, and explore the potential impact of technical innovations on FWE resources. Quantitative models are used in several studies to assess the potential of technological innovations or to understand FWE systems for decision-making or interventions. Examples include efficiencies in London's FWE metabolism (Villarroel Walker et al. 2014, 2017), strategies to adapt to seasonal variation in resource use and availability (Hussien et al. 2018), or ways to support decision-making focused on clean energy (Bieber et al. 2018). UA is well-represented. It is often cited as a potential, small-scale solution that shifts the focus from resource use to production. Studies noted multiple benefits, including rainwater capture for local agriculture (Amos et al. 2018), managed algae production to capture nitrogen and phosphorous run off (Dal Bo Zanon et al. 2017), and the reuse of wastewater in local agriculture (Miller-Robbie et al. 2017).

Two participatory studies fell into this category; both were centered on engaging stakeholders in problem-solution discussions, or scenarios. One tested a role-playing game focused on reducing household greenhouse gas emissions (Agusdinata and Lukosch 2019), while Treemore-Spears et al. (2016) used a stakeholder workshop to address complex, socio-historical FWE nexus inequalities.

\section{Tested solutions}

Tested solutions only comprised 9\% (5) papers, and the majority focused on UA. Sanjuan-Delmás et al. (2018) assessed the feasibility and impact of rooftop greenhouse gardening for food production. A four-step, Roof Mosaic approach was developed by Toboso-Chavero et al. (2019) as a way to integrate food and energy production, and rainwater harvesting in cities. Salvador et al. (2019) employed the Roof Mosaic approach to test the potential of a university technology park to be self-sustainable with respect to its FWE needs. Holt et al. (2017) redesigned plasticulture beds to optimize food production while increasing crop density, with pilot studies in the United States. 


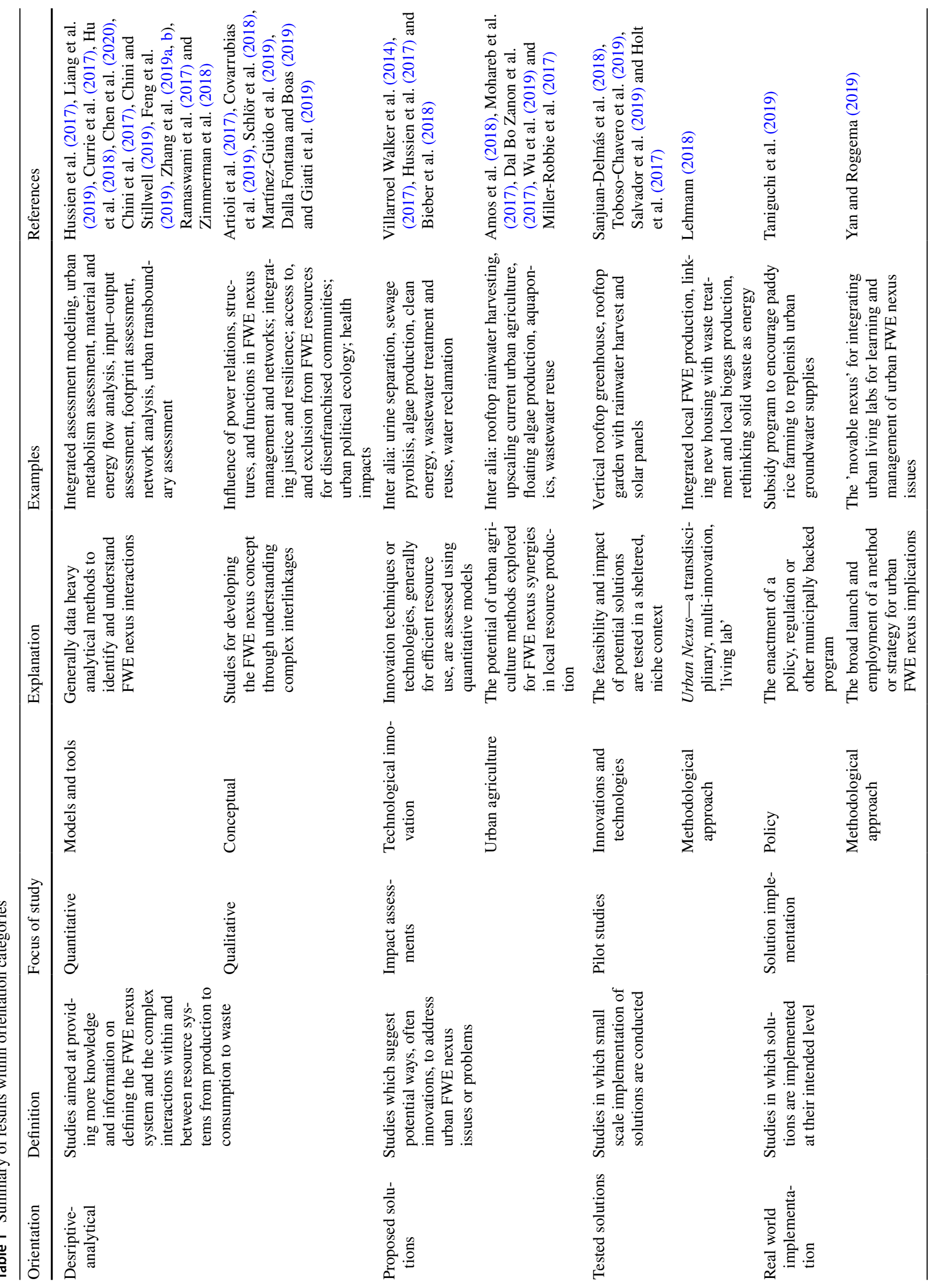


The final paper in this category tested a method developed by Vogt et al. (2014a, b) in the context of a United Nation's ESCAP, GIZ, and ICLEI project called the Urban Nexus. The authors described three case studies (in India, the Philippines, and Indonesia) that employed the Living Lab construct (Lehmann 2018). Each was influenced by ideas from the circular economy, and targeted FWE resource security, sustainability, and local agency and capacity development, linked with inexpensive, low-tech innovation.

\section{Real-world implementation}

Only two studies fell into this category. Taniguchi et al. (2019) examined the outcome of a program in Kumamoto, Japan, when the city determined that a fall in the water table was due to decreased upstream rice paddy farming. Subsidies were introduced to incentivize farmers to irrigate their rice fields. The study found that the initiative both stimulated economic growth, and replenished groundwater levels. However, the authors noted that should the subsidy lapse, these benefits were likely to disappear. In the second study, Yan and Roggema (2019) described the development and deployment of a design-led method. Named the 'moveable nexus', it was developed in an urban living lab, and integrated with existing labs in an effort to engage urban resources, technology and knowledge, and improve FWE nexus management.

\section{Participatory methods: actors and future steps}

Our analysis highlighted that participatory approaches are rarely used. Only 7\% (4) studies included participatory methods, and all of these involved solutions: two described proposed solutions, one presented tested solutions, and one concerned a real world implementation. At the same time, $45 \%$ (23) papers directly or indirectly implied the current or future involvement of non-academic actors. Only two (4\%) suggested future stakeholder participation in the development of solutions. Sixteen papers (29\%) proposed policy implications, which we understand to indicate the potential future use of findings by non-academic actors. Interviews featured in six papers (11\%). Although interviews are not strictly participatory, they can indicate the integration of non-academic knowledge systems. However, only in one study were resident stakeholders interviewed, while the remainder gathered information from experts and practitioners (Fig. 2).

\section{Participatory methods}

Three of the four participatory studies were described as transdisciplinary. Two of these used urban living labs (Lehmann 2018; Yan and Roggema 2019), and the third

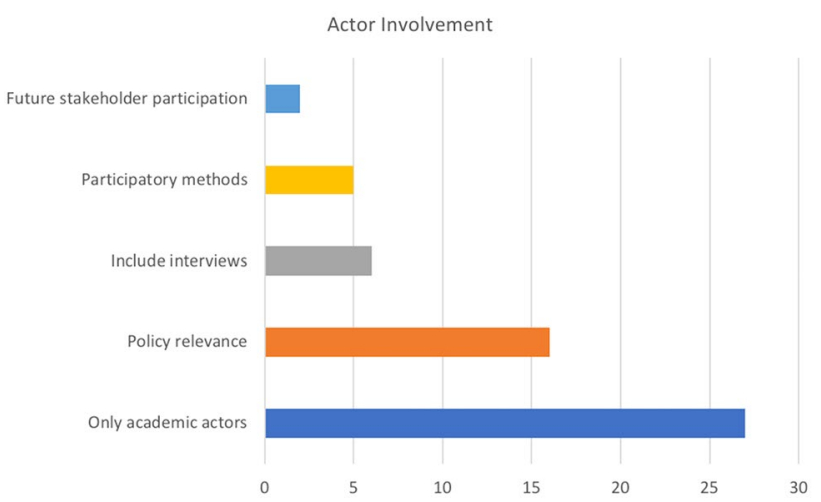

Fig. 2 Forms of actor involvement and the number of papers in which each form is indicated

deployed a game-based scenario (Agusdinata and Lukosch 2019). The fourth took the form of a stakeholder workshop (Treemore-Spears et al. 2016). Each proposes a different way forward: a return to descriptive-analytical approaches (Lehmann 2018), the diffusion of methods (Yan and Roggema 2019), building on the current study (Agusdinata and Lukosch 2019), and moving toward the implementation of solutions (Treemore-Spears et al. 2016).

\section{Potential future stakeholder integration}

Daher et al. (2019) and Schulterbrandt Gragg et al. (2018) were the only two, non-participatory papers that suggested the future, direct participation of stakeholders. Daher et al. (2019) developed a holistic tool, and suggested using its outputs to facilitate stakeholder dialogue, and develop strategic policies. Similarly, Schulterbrandt Gragg et al. (2018) developed a tool, aiming to run field tests that would raise the profile of social issues in urban food systems.

Villarroel Walker et al. (2017) conveyed a need for stakeholder engagement when they suggested that progress "now rests on developing an approach that works more closely with the linguistic, qualitative ways of articulating community hopes and fears, while preserving the networks of causal logic enabling privileged, non-foreclosing policy and technology interventions to be identified" (p. 16).

Although nine papers (16\%) proposed technology adoption or diffusion of methods as next steps, none provide details of potential methods or strategies. For example, Hussien et al. (2018) proposed an effective household water saving strategy in Duhok, Iraq, but did not indicate who would use this information, or how. Similarly, UA studies do not indicate pathways for the implementation of innovative solutions, such as floating production for coastal cities (Dal Bo Zanon et al. 2017), rooftop production (SanjuanDelmás et al. 2018; Toboso-Chavero et al. 2019; Salvador et al. 2019), or urban aquaponics (Wu et al. 2019). 


\section{Policy relevance}

A main application of the FWE nexus is in the management of resource systems. Therefore, it is not surprising that $29 \%$ of the studies in the dataset claimed to be policy relevant. However, none appeared to be directly connected to an ongoing or forthcoming policy process. Several studies addressed not what policies are needed, but rather how policies are made. For example, in the United States, Feng et al. (2019) advocated taking a holistic view of urban FWE in Detroit, Michigan. In Beijing, China, Li et al. (2019a, b) identified a hierarchy of critical FWE systems and subsystems, and Elagib et al. (2019) advocated integrated decision-making with respect to hazard management and the FWE nexus in Khartoum, Sudan. Finally, Lahmouri et al. (2019) showed the benefits of the decentralized management of FWE resources, emphasizing the need for decision-making among local people who are best-informed about the situation.

\section{Future research into societal actors}

Three papers suggested that further research should target societal actors. For instance, Artioli et al. (2017) suggested that research should identify actors who have the authority and capacity to drive integrated management, while Covarrubias and Boas (2019) and Covarrubias et al. (2019) advocated that there is a need for better coordination and skill-building among policy actors and governance networks.

\section{Discussion}

Our review reveals a clear disconnect between studies that describe the FWE nexus, those that propose and test solutions, and research into the implementation of these solutions. We identified three main gaps in operationalization, and opportunities to apply participatory, solution-oriented approaches. First, current approaches do not adequately take into account complex urban dynamics that must be integrated when localizing the concept, and its application. Second, the dominant technical solutions do not indicate how to integrate societal actors and their needs. Third, participatory methods remain nascent, and they seem to be a clear window of opportunity for solutions-focused approaches.

In this section, we discuss three broad shifts that can address these gaps and help change the focus from descriptive-analytical to solutions-based. The first is a conceptual shift that seeks to integrate urban complexity. The second aims to foster bottom-up interactions and impacts, and the third requires adapting solutions-based approaches to ensure that new knowledge production is credible, salient, and legitimate.

\section{Shifting the urban FWE nexus to solutions}

\section{Integrating urban complexity}

Urban nexus framing can help to integrate social complexity, and improve our understanding of a local nexus. Our review confirms that, as Romero-Lankao et al. (2017) suggest, this has already begun. Various issues have been shown to be relevant at the urban level: policies, inequalities, power, historical developments and cultural patterns, politics, and economics (Foran 2015; Keairns et al. 2016; Artioli et al. 2017; Covarrubias 2019; Dalla Fontana and Boas 2019). However, the preponderance of studies that propose or test technical or technological solutions, but do not address their implementation, confirms that little attention has been paid to developing specific solutions (e.g. Guan et al. 2020; Heard et al. 2017). Furthermore, the express integration of social complexities reflects the need for bottom-up projects, to understand multi-level, multi-sector synergies, and tradeoffs (Ramaswami et al. 2017). We recognize that integrating social dynamics into quantitative models is difficult, and that nexus researchers are often already overburdened by data. Therefore, we suggest that researchers accept the uncertainty that is inherent in local, context-specific dynamics, and develop pathways that link social and technical projects with higher-level nexus and sustainability goals and agendas.

\section{From top-down flows to bottom-up interventions}

Most of the tested solutions included in this review focus on the resource efficiency impacts of technological solutions. However, such solutions require significant upscaling, and buy-in from the public to have an impact. In this context, we found little evidence of a discussion about the trade-offs and opportunity costs of investing in, and implementing these solutions at the city level (Gondhalekar and Ramsauer 2017; Villarroel Walker et al. 2017).

Impacts from sustainability interventions in the nexus can appear at any level, due to the multi-scalar, multi-level interactions inherent in the nexus. Therefore, the second conceptual shift requires understanding urban FWE nexus interactions not only as incoming flows, but also as outgoing impacts. It is important to understand how the nexus system may respond to an intervention, to avoid unintentional, undesirable consequences (Chapin et al. 2010). This thinking reverses the directionality of flow-from a top-down model, where resources flow from source to use (Bijl et al. 2018) - to a bottom-up model, where the focus is on synergies and trade-offs from use to source. This conceptualization can also help to set boundaries regarding the depth and breadth of the social context (Sect. 4.1.1) associated with an identified FWE nexus sustainability problem (Garcia and You 2016). 


\section{Knowledge production}

The studies included in this review show that the knowledge necessary for developing and implementing solutions in the nexus is diverse and varied (e.g. Treemore-Spears et al. 2016; Lehmann 2018; Daher et al. 2019; Taniguchi et al. 2019; Agusdinata and Lukosch 2019). They also suggest that, at the implementation stage, certain types of knowledge are more important than others. Therefore, along with shifts in conceptualization, we suggest that the transition to a solutions-orientation requires a parallel shift in the credibility, salience, and legitimacy of academic knowledge. Making research actionable and acceptable is key; if this does not happen, sustainability solutions can become political, cultural, and economic footballs.

It is critical that researchers take into account the local political and socio-cultural context, and to understand how their study may disrupt that context, either now or in the future. Are appropriate municipal policy structures (e.g. integrated resource management pathways) in place? Have municipal departments asked for help? Is the study aligned with current or future planning, and strategies? Who are the actors that have the agency to turn knowledge into action, and what knowledge do they need to enable that action? Who are the potential winners and losers? What can be done to share benefits, and minimize inequalities? We argue that participatory approaches, which address these and other questions, can provide the credibility, salience, and legitimacy for solution-focused research.

\section{Sustainability and participatory approaches}

Nexus research requires a plurality of perspectives, interests, knowledge bases, and expertise (Howarth and Monasterolo 2016; Cairns and Krzywoszynska 2016; Kurian 2017; Allouche et al., 2018; Bergendahl et al. 2018; Shannak et al. 2018; Hoolohan et al. 2018). As Scanlon et al. (2017) state, "integrating multiple disciplines in science and academia, industry, and government holds great promise for transforming FEW science for societal benefit" (p. 3554). Yet, our review, like others, demonstrates that transdisciplinary approaches remain rare (Albrecht et al. 2018; Simpson and Jewitt 2019b; Newell et al. 2019). Nevertheless, our work reveals an opportunity to integrate participatory methods from sustainability science, and benefit from inter-and transdisciplinary learning and experience regarding local-level sustainability innovation, strategy implementation, and the governance of change processes (Halbe et al. 2015).

Sustainability science has emerged over the past 20 years, and seeks to address today's most pressing sustainability challenges (Kates 2001). Sustainability science research can be described as both descriptive-analytical and solutionsoriented (Lang et al. 2012). It aims to determine pathways to sustainability, through interventions that are often based on participatory processes. The latter propose and test actions that can result in societal change (Spangenberg 2011; Lang et al. 2012; Polk 2014). Participation assumes a level of coproduction with stakeholders and can, therefore, increase trust, confidence, and applicability to local contexts (Norström et al. 2020). Even short-term participatory approaches, such as the stakeholder workshop conducted by TreemoreSpears et al. (2016), can be seen to support actions that lead to a more just and sustainable society (Culwick et al. 2019). They, therefore, play a key role in the conceptual shifts that are discussed above, as they create a foundation for credible, salient, and legitimate knowledge (Cash et al. 2003).

Our review only identified two longer term participatory approaches (Lehmann 2018; Yan and Roggema 2019). Both studies developed, tested, and partially implemented local FWE nexus solutions, indicating the potential for such approaches. Transdisciplinary research seeks to bring together actors who can co-develop credible, salient, and legitimate knowledge, and implement solutions to sustainability problems within a specific context (Pohl and Hirsch Hadorn 2008; Hansson and Polk 2018). Learning is a key output; actors and stakeholders can become transformative change agents, who are able to apply diverse knowledge systems and perspectives to issues within and beyond the context (Gibbons 1994; Moser 2016). Transdisciplinarity has been used in the urban nexus context to obtain a more holistic understanding of the system (Bergendahl et al. 2018), notably its power dynamics (Bréthaut et al. 2019), and as a way to understand potential solution pathways (Agusdinata and Lukosch 2019). We argue that transdisciplinary processes should be used in multi-sector description-analysis studies that are linked with the development of interventions.

All of the tested solutions included in this review involved experimentation. Most addressed technical and technological solutions, but did not look at how they could be integrated and disseminated in society. In the context of sustainability science, experimentation is a way to test potential solutions to complex, local problems, and trigger a sustainability transition (Sengers et al. 2019). Lehmann (2018) illustrates a transdisciplinary, experimental process, which is often framed as an urban laboratory (UL). The method can bridge the technical and social divide, and help to identify relevant solution pathways.

There are several types of ULs; examples include Transition Labs, Urban Living Labs, City Labs, and Real World Labs (Bulkeley et al. 2016; Schäpke et al. 2018; Culwick et al. 2019). Many have emerged from the tradition of transition experiments (Nevens et al. 2013). According to Sengers, Wieczorek, and Raven (2019, p. 154), "society is itself a laboratory and a variety of real-world actors commit to the messy experimental processes tied up with the introduction of alternative technologies and practices to purposively 
re-shape social and material realities." Thus, ULs can embody the community integration and innovation called for by Villarroel Walker et al. (2017), and provide structure for the stakeholder dialogue proposed by Daher et al. (2019).

Both Lehmann (2018), and Yan and Roggema (2019) employed the Urban Living Lab approach. These two studies highlight the diversity and flexibility of such approaches. Lehmann (2018) show how local FWE land use, production, and delivery issues can be addressed through technological and system innovation, while Yan and Roggema (2019) develop an innovative design and collaboration process for local FWE projects.

\section{Conclusions and recommendations}

The concept of the FWE nexus is a significant step forward in understanding the complexity of human-environment interactions. It has the potential to integrate and, in some ways, operationalize the United Nation's Sustainable Development Goals (Liu et al. 2018; Vanham et al. 2019). However, gaps remain in ways to implement change processes that have desirable sustainability outcomes at multiple levels. Our study builds on the existing literature combining sustainability science and the FWE nexus. For example, Halbe et al. (2015) propose a framework for sustainability transition governance in the broader FWE nexus, and identify key aspects such as experimentation and stakeholder participation. Albrecht et al. (2018) note that innovation and collaboration are essential in moving the nexus agenda ahead; similarly, we argue that a focus on transdisciplinary experimentation is a promising way forward.

Our results lead us to propose the following recommendations. These recommendations are aimed at decision-makers who can facilitate the integration of UL approaches, and operationalize solutions on the ground. They are: (1) carry knowledge development through to the implementation of change strategies; (2) engage relevant stakeholders at all stages in the solutions process to align potential solutions with actors who have the agency to implement them; (3) move beyond flows and metabolism, and engage the behaviors, habits, and social patterns that underpin urban complexity; (4) include nexus thinking in participatory/ laboratory approaches, and (5) purposefully integrate research into municipal strategies and plans. Taken together, these five can align the goals of ULs and FWE initiatives. They can ensure that UL outcomes are directly relevant to a broader sustainability strategy, while creating pathways for a sustainability transition in the urban FWE nexus.

Carry knowledge development through to the implementation of change strategies. The FWE nexus literature provides a wealth of tools and models to help us understand how resource systems are entangled at multiple scales (Albrecht et al. 2018); however, this knowledge is rarely operationalized. Our review only identified three research teams that drew upon their previous work to advance toward implementation (Villarroel Walker et al. 2014, 2017; Chini et al. 2017; Hussien et al. 2017, 2018; Chini and Stillwell 2019). Linking context-specific descriptive-analytical research with solution-innovation approaches can optimize overall efforts, exploit synergies, and minimize trade-offs in time, energy, and funding. Coordinating research in this way would enable purposes and objectives that are co-defined with stakeholders on the ground to be aligned with learning and new knowledge that can be efficiently integrated into models and tools. Aligning top-down with bottom-up purposes also addresses the problem of ULs that are run in similar contexts, but which are often unconnected and uncoordinated (Hodson et al. in Marvin et al. 2018).

Engage relevant stakeholders at all stages of the solutions process to align potential solutions with actors who have the agency to implement them. Although participation takes various forms, it is essential to have a core set of key actors and stakeholders who are in a committed partnership with academic institutions to co-define and co-develop a UL. The composition of the project team is critical in establishing the credibility, salience, and legitimacy of outcomes, but it is important to consider this as an open, inclusive, and reflexive process.

The UL often exists across multiple contexts (e.g. social, cultural, political, organizational, and institutional), all of which may have different criteria regarding credibility, salience, and legitimacy (Hansson and Polk 2018). Therefore, it is important to involve and coordinate stakeholders (Covarrubias et al. 2019) who have the agency and capacity to deploy resources in a timely manner (Seyfang et al. 2010; Brown and Westaway 2011; Frantzeskaki et al. 2014; Covarrubias and Boas 2019). Cultivating key public and private sector connections may require a sustained effort to establish trust and buy-in, as short- and long-term planning, coordination, and redundancy are essential for projects to unfold smoothly. Moreover, as the UL evolves, actors or actor groups will shift from the center to the periphery, and back again. Who is 'sitting at the table', at what time during the process, can influence the boundaries of the negotiation between what should be done, and what can be done in the UL.

Move beyond flows and metabolism, and engage the behaviors, habits, and social patterns that underpin urban complexity. Broadening the descriptive analysis to include patterns of resource use can be key to nexus sustainability, as these patterns are supported by systems and habits that are held in place by culture, society, and individual preference. FWE resource access, affordability, knowledge, and options are not equally distributed through city communities and populations. Therefore, neither problems nor solutions 
may lie within the resource system, but in the underlying societal structures that guide development (Allouche et al. 2015; Foran 2015). The underlying causal elements/interactions, and their enabling conditions may be determined by understanding the complexity surrounding resource use (Halbe et al. 2015). This, in turn, can open up a dialogue about where to focus efforts to obtain the desired impact. Following on from this, strategies for change can be developed, which may require coordinated efforts across scales, sectors, and levels (King and Carbajales-Dale 2016).

Include nexus thinking in participatory/ laboratory approaches. The outcomes of UL processes, "have the potential to be scaled up across systems of provision to achieve sustainability transitions at a large scale" (Marvin et al. 2018, p. 1) - but only if they are incorporated into higher level strategies and agendas, such as the FWE nexus. Identifying cross-level synergies in FWE resource systems can open up a new perspective that moves learning to multi-level networks, and municipal agencies/ authorities. For example, Engström et al. (2018) found a mismatch between local, sustainable energy choices (biofuels), and unsustainable water resource outcomes in biofuel production regions. Understanding such crossscale and cross-sector trade-offs is key to sustainability in the FWE nexus (D'Odorico et al. 2018). However, ULs often focus too closely on local issues, and neglect unsustainable, unintended consequences elsewhere. At the same time, ULs are well-suited to uncovering, and taking advantage of synergies between social and material flows (Covarrubias 2019). Identifying and understanding the dynamics of interconnections between these flows can have a significant influence on the innovative, experimental solution options in the UL, and their potential impact (Luederitz et al. 2017; Forrest et al. 2019).

Purposefully integrate research into municipal strategies and plans. The implementation of the nexus agenda will require multi-level coordination of policies and policy fields (Pahl-Wostl 2019); it must transcend sectoral divisions, and transform approaches to resource use and management. Municipal authorities often have regulatory power over the flow and trade of FWE resources, notably infrastructure investment (or the lack of), which is highly relevant to issues of resource access, affordability, and delivery (Artioli et al. 2017). ULs benefit from institutional level support that can link outcomes to broader sustainability transitions (Evans and Karvonen 2014; Bulkeley et al. 2018). The judicious selection of actors can ensure that high-level agendas are integrated into UL priorities, and that knowledge production is aimed at critical issues, such as the Sustainable Development Goals (Liu et al. 2018; Simpson and Jewitt 2019b). However, this is not without challenges. Hodson et al. (in Marvin et al. 2018) note that coordination requires knowledge, skills, and time. Moreover, the municipality must be onboard, and be able to make personnel available to participate in a variety of labs that might be running at any given time (Yan and Roggema 2019). Staff must have the capacity to aggregate the learning and knowledge that is developed, and have the agency to translate it into policy or other actions (Covarrubias and Boas 2019).

Given the multi-scale complexities of the FWE nexus and the ever-growing importance of cities in global environmental sustainability, we anticipate an expansion of solution-focused approaches. The latter must be contextually relevant, and implementable to meet sustainability and security goals. Our recommendations take into account the potential to integrate transdisciplinary experimentation research at urban and local levels with policy strategies. Moreover, including policymakers in the process would heighten the relevance and urgency of FWE nexus project outcomes. Given the recent surge in interest in the FWE nexus, we hope that the focus turns toward developing solution pathways that link levels and agendas to implement change in policy and practice.

Acknowledgements This research was conducted as part of the GLOCULL Project (Belmont Forum) and funded by the Swedish Energy Agency. The authors would like to thank the anonymous reviewers for their time and comments.

Funding Open Access funding provided by Lund University.

Open Access This article is licensed under a Creative Commons Attribution 4.0 International License, which permits use, sharing, adaptation, distribution and reproduction in any medium or format, as long as you give appropriate credit to the original author(s) and the source, provide a link to the Creative Commons licence, and indicate if changes were made. The images or other third party material in this article are included in the article's Creative Commons licence, unless indicated otherwise in a credit line to the material. If material is not included in the article's Creative Commons licence and your intended use is not permitted by statutory regulation or exceeds the permitted use, you will need to obtain permission directly from the copyright holder. To view a copy of this licence, visit http://creativecommons.org/licenses/by/4.0/.

\section{References}

Agusdinata DB, Lukosch H (2019) Supporting interventions to reduce household greenhouse gas emissions: a transdisciplinary roleplaying game development. Simul Gaming 50:359-376. https:// doi.org/10.1177/1046878119848135

Alberti M, McPhearson T, Gonzalez A (2018) Embracing urban complexity. In: Elmqvist T, Bai X, Frantzeskaki N et al (eds) Urban Planet, 1st edn. Cambridge University Press, Cambridge, pp 45-67

Albrecht TR, Crootof A, Scott CA (2018) The water-energy-food nexus: a systematic review of methods for nexus assessment Environ Res Lett 13:043002. https://doi.org/10.1088/1748-9326/ aaa9c6 
Allouche, J, Middleton C and Gyawali, D (2018) Chapter 4-The knowledge nexus and transdisciplinarity. In: The water-foodenergy nexus: power, politics and justice, 1st edn. RoutledgeEarthscan, London

Allouche J, Middleton C, Gyawali D (2015) Technical veil, hidden politics: interrogating the power linkages behind the nexus. Water Altern 8:17

Amos CC, Rahman A, Karim F, Gathenya JM (2018) A scoping review of roof harvested rainwater usage in urban agriculture: Australia and Kenya in focus. J Clean Prod 202:174-190. https://doi. org/10.1016/j.jclepro.2018.08.108

Artioli F, Acuto M, McArthur J (2017) The water-energy-food nexus: an integration agenda and implications for urban governance. Polit Geogr 61:215-223. https://doi.org/10.1016/j.polge o.2017.08.009

Bazilian M, Rogner H, Howells M et al (2011) Considering the energy, water and food nexus: Towards an integrated modelling approach. Energy Policy 39:7896-7906. https://doi.org/10.1016/j.enpol .2011.09.039

Bergendahl JA, Sarkis J, Timko MT (2018) Transdisciplinarity and the food energy and water nexus: Ecological modernization and supply chain sustainability perspectives. Resour Conserv Recycl 133:309-319. https://doi.org/10.1016/j.resconrec.2018.01.001

Bieber N, Ker JH, Wang X et al (2018) Sustainable planning of the energy-water-food nexus using decision making tools. Energy Policy 113:584-607. https://doi.org/10.1016/j.enpol.2017.11.037

Bijl DL, Bogaart PW, Dekker SC, van Vuuren DP (2018) Unpacking the nexus: different spatial scales for water, food and energy. Glob Environ Change 48:22-31. https://doi.org/10.1016/j.gloen vcha.2017.11.005

Bréthaut C, Gallagher L, Dalton J, Allouche J (2019) Power dynamics and integration in the water-energy-food nexus: Learning lessons for transdisciplinary research in Cambodia. Environ Sci Policy 94:153-162. https://doi.org/10.1016/j.envsci.2019.01.010

Brown K, Westaway E (2011) Agency, capacity, and resilience to environmental change: lessons from human development, well-being, and disasters. Annu Rev Environ Resour 36:321-342. https://doi. org/10.1146/annurev-environ-052610-092905

Bulkeley H, Coenen L, Frantzeskaki N et al (2016) Urban living labs: governing urban sustainability transitions. Curr Opin Environ Sustain 22:13-17. https://doi.org/10.1016/j.cosust.2017.02.003

Bulkeley H, Marvin S, Palgan YV et al (2018) Urban living laboratories: conducting the experimental city? Eur Urban Reg Stud. https://doi.org/10.1177/0969776418787222

Cairns R, Krzywoszynska A (2016) Anatomy of a buzzword: the emergence of 'the water-energy-food nexus' in UK natural resource debates. Environ Sci Policy 64:164-170. https://doi. org/10.1016/j.envsci.2016.07.007

Cash DW, Clark WC, Alcock F et al (2003) Knowledge systems for sustainable development. Proc Natl Acad Sci 100:8086-8091. https://doi.org/10.1073/pnas.1231332100

Chapin FS, Carpenter SR, Kofinas GP et al (2010) Ecosystem stewardship: sustainability strategies for a rapidly changing planet. Trends Ecol Evol 25:241-249. https://doi.org/10.1016/j. tree.2009.10.008

Chen I-C, Wang Y-H, Lin W, Ma H (2020) Assessing the risk of the food-energy-water nexus of urban metabolism: a case study of Kinmen Island. Taiwan Ecol Indic 110:105861. https://doi. org/10.1016/j.ecolind.2019.105861

Chini CM, Konar M, Stillwell AS (2017) Direct and indirect urban water footprints of the United States: URBAN WATER FOOTPRINTS. Water Resour Res 53:316-327. https://doi. org/10.1002/2016WR019473

Chini CM, Stillwell AS (2019) The metabolism of U.S. cities 2.0. J Ind Ecol 23:1353-1362. https://doi.org/10.1111/jiec.12923
Chirisa I, Bandauko E (2015) African cities and the water-food-climate-energy nexus: an agenda for sustainability and resilience at a local level. Urban Forum 26:391-404. https://doi.org/10.1007/ s12132-015-9256-6

Covarrubias M (2019) The nexus between water, energy and food in cities: towards conceptualizing socio-material interconnections. Sustain Sci 14:277-287. https://doi.org/10.1007/s1162 5-018-0591-0

Covarrubias M, Boas I (2019) The making of a sustainable food city in Barcelona: insights from the water, energy, and food urban nexus. J Integr Environ Sci. https://doi.org/10.1080/19438 15X.2019.1675715

Covarrubias M, Spaargaren G, Boas I (2019) Network governance and the Urban Nexus of water, energy, and food: lessons from Amsterdam. Energy Sustain Soc. https://doi.org/10.1186/s1370 5-019-0196-1

Culwick C, Washbourne C-L, Anderson PML et al (2019) CityLab reflections and evolutions: nurturing knowledge and learning for urban sustainability through co-production experimentation. Curr Opin Environ Sustain 39:9-16. https://doi.org/10.1016/j. cosust.2019.05.008

Currie PK, Musango JK, May ND (2017) Urban metabolism: a review with reference to Cape Town. Cities 70:91-110. https://doi. org/10.1016/j.cities.2017.06.005

Daher B, Lee S-H, Kaushik V et al (2019) Towards bridging the water gap in Texas: a water-energy-food nexus approach. Sci Total Environ 647:449-463. https://doi.org/10.1016/j.scito tenv.2018.07.398

Dal Bo ZB, Roeffen B, Czapiewska KM et al (2017) Potential of floating production for delta and coastal cities. J Clean Prod 151:10 20. https://doi.org/10.1016/j.jclepro.2017.03.048

Dalla Fontana M, Boas I (2019) The politics of the nexus in the city of Amsterdam. Cities 95:102388. https://doi.org/10.1016/j.citie s.2019.102388

D'Odorico P, Davis KF, Rosa L et al (2018) The global foodenergy-water nexus. Rev Geophys 56:456-531. https://doi. org/10.1029/2017RG000591

Elagib NA, Gayoum Saad SA, Basheer M et al (2019) Exploring the urban water-energy-food nexus under environmental hazards within the Nile. Stoch Environ Res Risk Assess. https://doi. org/10.1007/s00477-019-01706-x

Endo A, Tsurita I, Burnett K, Orencio PM (2017) A review of the current state of research on the water, energy, and food nexus. J Hydrol Reg Stud 11:20-30. https://doi.org/10.1016/j. ejrh.2015.11.010

Engström RE, Howells M, Destouni G (2018) Water impacts and water-climate goal conflicts of local energy choices-notes from a Swedish perspective. Proc Int Assoc Hydrol Sci 376:25-33. https://doi.org/10.5194/piahs-376-25-2018

Evans J, Karvonen A (2014) 'Give Me a Laboratory and I Will Lower Your Carbon Footprint!'-urban laboratories and the governance of low-carbon futures: governance of low carbon futures in Manchester. Int J Urban Reg Res 38:413-430. https ://doi.org/10.1111/1468-2427.12077

Feng C, Qu S, Jin Y et al (2019) Uncovering urban food-energywater nexus based on physical input-output analysis: The case of the Detroit Metropolitan Area. Appl Energy 252:113422. https://doi.org/10.1016/j.apenergy.2019.113422

Foran T (2015) Node and regime: interdisciplinary analysis of waterenergy-food nexus in the Mekong region. 8:21

Forrest N, Stein Z, Wiek A (2019) Water-independent residential properties as a transformational solution to achieve water sustainability in desert cities? J Clean Prod 214:1038-1049. https ://doi.org/10.1016/j.jclepro.2018.12.309

Frantzeskaki N, Loorbach D, Meadowcroft J (2012) Governing societal transitions to sustainability. Int J Sustain Dev 15:19-36 
Frantzeskaki N, Wittmayer J, Loorbach D (2014) The role of partnerships in 'realising' urban sustainability in Rotterdam's City Ports Area, The Netherlands. J Clean Prod 65:406-417. https ://doi.org/10.1016/j.jclepro.2013.09.023

Fuenfschilling L, Frantzeskaki N, Coenen L (2019) Urban experimentation and sustainability transitions. Eur Plan Stud 27:219228. https://doi.org/10.1080/09654313.2018.1532977

Funtowicz SO, Ravetz JR (1993) Science for the post-normal age. Futures 25:739-755. https://doi.org/10.1016/00163287(93)90022-1

Future Earth (2018) Research and engagement plan for the waterenergy-food knowledge-action network, Report of the Development Team. Future Earth Secretariat

Garcia DJ, You F (2016) The water-energy-food nexus and process systems engineering: a new focus. Comput Chem Eng 91:49-67. https://doi.org/10.1016/j.compchemeng.2016.03.003

Giatti LL, Urbinatti AM, de Carvalho CM et al (2019) Nexus of exclusion and challenges for sustainability and health in an urban periphery in Brazil. Cad Saúde Pública. https://doi. org/10.1590/0102-311x00007918

Gibbons M (ed) (1994) The new production of knowledge: the dynamics of science and research in contemporary societies. Sage, London

Gondhalekar D, Ramsauer T (2017) Nexus City: operationalizing the urban water-energy-food nexus for climate change adaptation in Munich, Germany. Urban Clim 19:28-40. https://doi. org/10.1016/j.uclim.2016.11.004

Grimm NB, Faeth SH, Golubiewski NE et al (2008) Global change and the ecology of cities. Science 319:756-760. https://doi. org/10.1126/science. 1150195

Guan X, Mascaro G, Sampson D, Maciejewski R (2020) A metropolitan scale water management analysis of the food-energywater nexus. Sci Total Environ 701:134478. https://doi. org/10.1016/j.scitotenv.2019.134478

Halbe J, Pahl-Wostl C, A. Lange M, Velonis C, (2015) Governance of transitions towards sustainable development - the waterenergy-food nexus in Cyprus. Water Int 40:877-894. https:// doi.org/10.1080/02508060.2015.1070328

Hansson S, Polk M (2018) Assessing the impact of transdisciplinary research: The usefulness of relevance, credibility, and legitimacy for understanding the link between process and impact. Res Eval 27:132-144. https://doi.org/10.1093/reseval/rvy004

Heard BR, Miller SA, Liang S, Xu M (2017) Emerging challenges and opportunities for the food-energy-water nexus in urban systems. Curr Opin Chem Eng 17:48-53. https://doi. org/10.1016/j.coche.2017.06.006

Hoff H (2011) Understanding the Nexus. Stockholm Environment Institute, Bonn

Holt N, Shukla S, Hochmuth G et al (2017) Transforming the foodwater-energy-land-economic nexus of plasticulture production through compact bed geometries. Adv Water Resour 110:515527. https://doi.org/10.1016/j.advwatres.2017.04.023

Hoolohan C, Larkin A, McLachlan C et al (2018) Engaging stakeholders in research to address water-energy-food (WEF) nexus challenges. Sustain Sci 13:1415-1426. https://doi.org/10.1007/ s11625-018-0552-7

Howarth C, Monasterolo I (2016) Understanding barriers to decision making in the UK energy-food-water nexus: the added value of interdisciplinary approaches. Environ Sci Policy 61:53-60. https ://doi.org/10.1016/j.envsci.2016.03.014

Hu M-C, Fan C, Huang T et al (2018) Urban metabolic analysis of a food-water-energy system for sustainable resources management. Int J Environ Res Public Health 16:90. https://doi. org/10.3390/ijerph16010090

Hussien WA, Memon FA, Savic DA (2017) An integrated model to evaluate water-energy-food nexus at a household scale.
Environ Model Softw 93:366-380. https://doi.org/10.1016/j. envsoft.2017.03.034

Hussien WA, Memon FA, Savic DA (2018) A risk-based assessment of the household water-energy-food nexus under the impact of seasonal variability. J Clean Prod 171:1275-1289. https://doi. org/10.1016/j.jclepro.2017.10.094

Kates RW (2001) Sustainability science. Science 292:4-11. https://doi. org/10.1126/science.1059386

Keairns DL, Darton RC, Irabien A (2016) The energy-water-food nexus. Annu Rev Chem Biomol Eng 7:239-262. https://doi. org/10.1146/annurev-chembioeng-080615-033539

King CW, Carbajales-Dale M (2016) Food-energy-water metrics across scales: project to system level. J Environ Stud Sci 6:39-49. https://doi.org/10.1007/s13412-016-0390-9

Kurian M (2017) The water-energy-food nexus: Trade-offs, thresholds and transdisciplinary approaches to sustainable development. Environ Sci Policy 68:97-106. https://doi.org/10.1016/j.envsc i.2016.11.006

Lahmouri M, Drewes JE, Gondhalekar D (2019) Analysis of greenhouse gas emissions in centralized and decentralized water reclamation with resource recovery strategies in Leh Town, Ladakh, India, and potential for their reduction in context of the waterenergy-food nexus. Water 11:906. https://doi.org/10.3390/w1105 0906

Lang DJ, Wiek A, Bergmann M et al (2012) Transdisciplinary research in sustainability science: Practice, principles, and challenges. Sustain Sci 7:25-43. https://doi.org/10.1007/s11625-011-0149-x

Law J (1992) Notes on the theory of the actor-network: ordering, strategy, and heterogeneity. Syst Pract 5:379-393. https://doi. org/10.1007/BF01059830

Leck H, Conway D, Bradshaw M, Rees J (2015) Tracing the waterenergy-food nexus: description, theory and practice. Geogr Compass 9:445-460. https://doi.org/10.1111/gec3.12222

Lehmann S (2018) Implementing the Urban Nexus approach for improved resource-efficiency of developing cities in Southeast-Asia. City Cult Soc 13:46-56. https://doi.org/10.1016/j. ccs.2017.10.003

Li G, Huang D, Sun C, Li Y (2019a) Developing interpretive structural modeling based on factor analysis for the water-energy-food nexus conundrum. Sci Total Environ 651:309-322. https://doi. org/10.1016/j.scitotenv.2018.09.188

Li G, Wang Y, Li Y (2019b) Synergies within the water-energy-food nexus to support the integrated urban resources governance. Water 11:2365. https://doi.org/10.3390/w11112365

Liang S, Qu S, Zhao Q et al (2019) Quantifying the urban foodenergy-water nexus: the case of the Detroit metropolitan area. Environ Sci Technol 53:779-788. https://doi.org/10.1021/acs. est. 8 b06240

Liu J, Hull V, Godfray HCJ et al (2018) Nexus approaches to global sustainable development. Nat Sustain 1:466-476. https://doi. org/10.1038/s41893-018-0135-8

Liu J, Yang H, Cudennec C et al (2017) Challenges in operationalizing the water-energy-food nexus. Hydrol Sci J 62:1714-1720. https ://doi.org/10.1080/02626667.2017.1353695

Luederitz C, Schäpke N, Wiek A et al (2017) Learning through evaluation-a tentative evaluative scheme for sustainability transition experiments. J Clean Prod 169:61-76. https://doi.org/10.1016/j. jclepro.2016.09.005

Martínez-Guido SI, González-Campos JB, Ponce-Ortega JM (2019) Strategic planning to improve the Human Development Index in disenfranchised communities through satisfying food, water and energy needs. Food Bioprod Process 117:14-29. https://doi. org/10.1016/j.fbp.2019.06.007

Marvin S, Bulkeley H, Mai L et al (eds) (2018) Urban living labs: experimenting with city futures. Routledge, London 
McPhearson T, Pickett ST, Grimm NB et al (2016) Advancing urban ecology toward a science of cities. Bioscience 66:198-212

Miller-Robbie L, Ramaswami A, Amerasinghe P (2017) Wastewater treatment and reuse in urban agriculture: exploring the food, energy, water, and health nexus in Hyderabad. India Environ Res Lett 12:075005. https://doi.org/10.1088/1748-9326/aa6bfe

Mohareb E, Heller M, Novak P et al (2017) Considerations for reducing food system energy demand while scaling up urban agriculture. Environ Res Lett 12:125004. https://doi.org/10.1088/1748-9326/ aa889b

Moser SC (2016) Can science on transformation transform science? Lessons from co-design. Curr Opin Environ Sustain 20:106-115. https://doi.org/10.1016/j.cosust.2016.10.007

Nevens F, Frantzeskaki N, Gorissen L, Loorbach D (2013) Urban Transition Labs: co-creating transformative action for sustainable cities. J Clean Prod 50:111-122. https://doi.org/10.1016/j. jclepro.2012.12.001

Newell JP, Goldstein B, Foster A (2019) A 40-year review of foodenergy-water nexus literature and its application to the urban scale. Environ Res Lett 14:073003. https://doi.org/10.1088/17489326/ab0767

Norström AV, Cvitanovic C, Löf MF et al (2020) Principles for knowledge co-production in sustainability research. Nat Sustain. https ://doi.org/10.1038/s41893-019-0448-2

Pahl-Wostl C (2019) Governance of the water-energy-food security nexus: a multi-level coordination challenge. Environ Sci Policy 92:356-367. https://doi.org/10.1016/j.envsci.2017.07.017

Pohl C, Hirsch Hadorn G (2008) Methodological challenges of transdisciplinary research. Nat Sci Sociétés 16:111-121. https://doi. org/10.1051/nss:2008035

Polk M (2014) Achieving the promise of transdisciplinarity: a critical exploration of the relationship between transdisciplinary research and societal problem solving. Sustain Sci 9:439-451. https://doi. org/10.1007/s11625-014-0247-7

Ramaswami A, Boyer D, Nagpure AS et al (2017) An urban systems framework to assess the trans-boundary food-energywater nexus: implementation in Delhi, India. Environ Res Lett 12:025008. https://doi.org/10.1088/1748-9326/aa5556

Romero-Lankao P, McPhearson T, Davidson DJ (2017) The foodenergy-water nexus and urban complexity. Nat Clim Change 7:233-235. https://doi.org/10.1038/nclimate3260

Salvador DS, Toboso-Chavero S, Nadal A et al (2019) Potential of technology parks to implement Roof Mosaic in Brazil. J Clean Prod 235:166-177. https://doi.org/10.1016/j.jclepro.2019.06.214

Sanjuan-Delmás D, Llorach-Massana P, Nadal A et al (2018) Environmental assessment of an integrated rooftop greenhouse for food production in cities. J Clean Prod 177:326-337. https://doi. org/10.1016/j.jclepro.2017.12.147

Scanlon BR, Ruddell BL, Reed PM et al (2017) The food-energywater nexus: transforming science for society. Water Resour Res 53:3550-3556. https://doi.org/10.1002/2017WR020889

Schäpke N, Stelzer F, Caniglia G et al (2018) Jointly experimenting for transformation? Shaping real-world laboratories by comparing them. GAIA Ecol Perspect Sci Soc 27:85-96. https://doi. org/10.14512/gaia.27.S1.16

Schlör H, Venghaus S, Hake J-F (2018) The FEW-Nexus city indexmeasuring urban resilience. Appl Energy 210:382-392. https:// doi.org/10.1016/j.apenergy.2017.02.026

Schulterbrandt Gragg R, Anandhi A, Jiru M, Usher KM (2018) A conceptualization of the urban food-energy-water nexus sustainability paradigm: modeling from theory to practice. Front Environ Sci. https://doi.org/10.3389/fenvs.2018.00133

Sengers F, Wieczorek AJ, Raven R (2019) Experimenting for sustainability transitions: a systematic literature review. Technol Forecast Soc Change 145:153-164. https://doi.org/10.1016/j.techf ore.2016.08.031
Seyfang G, Haxeltine A, Hargreaves T, Longhurst N (2010) Energy and communities in transition-towards a new research agenda on agency and civil society in sustainability transitions. CSERGE Work Pap EDM No 10-13:1-21

Shannak S, Mabrey D, Vittorio M (2018) Moving from theory to practice in the water-energy-food nexus: an evaluation of existing models and frameworks. Water-Energy Nexus 1:17-25. https:// doi.org/10.1016/j.wen.2018.04.001

Simpson GB, Jewitt GP (2019a) The water-energy-food nexus in the anthropocene: moving from 'nexus thinking' to 'nexus action.' Curr Opin Environ Sustain 40:117-123. https://doi. org/10.1016/j.cosust.2019.10.007

Simpson GB, Jewitt GPW (2019b) The Development of the waterenergy-food nexus as a framework for achieving resource security: a review. Front Environ Sci. https://doi.org/10.3389/fenvs .2019 .00008

Spangenberg JH (2011) Sustainability science: a review, an analysis and some empirical lessons. Environ Conserv 38:275-287. https ://doi.org/10.1017/S0376892911000270

Taniguchi M, Burnett KM, Shimada J et al (2019) Recovery of lost nexus synergy via payment for environmental services in Kumamoto, Japan. Front Environ Sci. https://doi.org/10.3389/fenvs .2019 .00028

Toboso-Chavero S, Nadal A, Petit-Boix A et al (2019) Towards productive cities: environmental assessment of the food-energy-water nexus of the urban roof mosaic. J Ind Ecol 23:767-780. https:// doi.org/10.1111/jiec.12829

Topi C, Esposto E, Marini Govigli V (2016) The economics of green transition strategies for cities: Can low carbon, energy efficient development approaches be adapted to demand side urban water efficiency? Environ Sci Policy 58:74-82. https://doi. org/10.1016/j.envsci.2016.01.001

Treemore-Spears LJ, Grove JM, Harris CK et al (2016) A workshop on transitioning cities at the food-energy-water nexus. J Environ Stud Sci 6:90-103. https://doi.org/10.1007/s13412-016-0381-x

Vanham D, Leip A, Galli A et al (2019) Environmental footprint family to address local to planetary sustainability and deliver on the SDGs. Sci Total Environ 693:133642. https://doi.org/10.1016/j. scitotenv.2019.133642

Villarroel Walker R, Beck MB, Hall JW et al (2014) The energywater-food nexus: strategic analysis of technologies for transforming the urban metabolism. J Environ Manag 141:104-115. https://doi.org/10.1016/j.jenvman.2014.01.054

Villarroel Walker R, Beck MB, Hall JW et al (2017) Identifying key technology and policy strategies for sustainable cities: a case study of London. Environ Dev 21:1-18. https://doi.org/10.1016/j. envdev.2016.11.006

Vogt C, Schlenk JC, Horne C, Gügel C (2014a) Operationalizing the Urban NEXUS towards resource-efficient and integrated cities and metropolitan regions: Case Studies. Deutsche Gesellschaft für Internationale Zusammenarbeit (GIZ) $\mathrm{GmbH}$

Vogt C, Zimmermann M, Brekke K (2014b) Operationalizing the Urban NEXUS: Towards resource-efficient and integrated cities and metropolitan regions. GIZ and ICLEI

Waughray D (2011) Water security: the water-food-energy-climate nexus, Washington. The World Economic Forum Water Initiative. Island Press, Washington

Westley FR, Tjornbo O, Schultz L et al (2013) A Theory of Transformative Agency in Linked Social-Ecological Systems. Ecol Soc 18:

Wiek A, Lang DJ (2016) Transformational sustainability research methodology. In: Heinrichs H, Martens P, Michelsen G, Wiek A (eds) Sustainability science. Springer, Dordrecht, pp 31-41

Wu F, Ghamkhar R, Ashton W, Hicks AL (2019) Sustainable seafood and vegetable production: aquaponics as a potential opportunity in urban areas. Integr Environ Assess Manag 15:832-843. https ://doi.org/10.1002/ieam.4187 
Yan W, Roggema R (2019) Developing a in design-led approach for the food-energy-water nexus cities. Urban Plan 4:123. https:// doi.org/10.17645/up.v4i1.1739

Zhang P, Zhang L, Chang Y et al (2019) Food-energy-water (FEW) nexus for urban sustainability: a comprehensive review. Resour Conserv Recycl 142:215-224. https://doi.org/10.1016/j.resco nrec.2018.11.018

Zhang P, Zhang L, Hao Y et al (2019) Understanding the tele-coupling mechanism of urban food-energy-water nexus: critical sources, nodes, and supply chains. J Clean Prod 235:297-307. https://doi. org/10.1016/j.jclepro.2019.06.232
Zimmerman R, Zhu Q, Dimitri C (2018) A network framework for dynamic models of urban food, energy and water systems (FEWS). Environ Prog Sustain Energy 37(1):122-131. https:// doi.org/10.1002/ep.12699

Publisher's Note Springer Nature remains neutral with regard to jurisdictional claims in published maps and institutional affiliations. 